\title{
Selectivity of the herbicide metribuzin for pre- and post-emergence applications in potato cultivation
}

\section{Seletividade do herbicida metribuzin para batata em aplicação em pré e pós-emergência}

\author{
Núbia Maria Correia $^{1 *}$; Agnaldo Donizete Ferreira de Carvalho ${ }^{1}$
}

\begin{abstract}
Metribuzin is the most commonly used herbicide in potato cultivation in Brazil, but there are few reports in literature regarding its selectivity, especially when applied to post-emergent potato plants. The objective of this study was to evaluate the selectivity of the herbicide metribuzin for potato cultivation, applied in pre-and post-emergence. Two experiments were carried out under field conditions, one with the Agata cultivar and another with the Atlantic cultivar. A randomized block experimental design, with a subdivided plot $(5 \times 3)$ and four replications, was used in both experiments. Plot experiments consisted of five doses of metribuzin $\left(0,120,240,360\right.$, and $480 \mathrm{~g}$ a.i. ha $\left.{ }^{-1}\right)$, studied for pre-emergence, as well as three doses $\left(0,120\right.$, and $192 \mathrm{~g}$ a.i. ha $\left.{ }^{-1}\right)$ studied for post-emergence. Metribuzin was selective for the Agata and Atlantic cultivars at doses of up to $480 \mathrm{~g} \mathrm{ha}^{-1}$ for pre-emergence, as well as at 120 or $192 \mathrm{~g} \mathrm{ha}^{-1}$ for post-emergence, applied seven days after hilling.
\end{abstract}

Key words: Agata. Atlantic. Phytotoxicity. Solanum tuberosum L.

\section{Resumo}

O metribuzin é o herbicida mais utilizado na cultura da batata no Brasil, porém existem poucos relatos na literatura sobre a sua seletividade, principalmente, quando aplicado na pós-emergência das plantas de batata. Com o objetivo de estudar a seletividade do herbicida metribuzin para a cultura da batata, aplicadoem pré e pós-emergência, dois experimentos foram desenvolvidos em condições de campo, um com a cultivar Ágata e outro com a Atlantic. Nos dois experimentos, o delineamento experimental foi o de blocos ao acaso, em esquema de parcela subdividida ( $5 \times 3)$, com quatro repetições. Nas parcelas foram estudadas cinco doses de metribuzin $\left(0,120,240,360,480 \mathrm{~g}\right.$ i.a. ha $\left.{ }^{-1}\right)$, em pré-emergência, após o plantio da batata, combinadas à aplicação de três doses desse herbicida $\left(0,120\right.$ e $192 \mathrm{~g}$ i.a. ha $\left.{ }^{-1}\right)$, em pósemergência das plantas, nas subparcelas. O metribuzin foi seletivo para as cultivares Ágata e Atlantic em doses de até $480 \mathrm{~g} \mathrm{ha}^{-1}$ em pré-emergência combinado com 120 ou $192 \mathrm{~g} \mathrm{ha}^{-1}$ em pós-emergência, aplicado aos sete dias após a prática da amontoa.

Palavras-chave: Ágata. Atlantic. Fitointoxicação. Solanum tuberosum L.

1 Drs., Pesquisadores, Empresa Brasileira de Pesquisa Agropecuária, EMBRAPA Hortaliças, Brasília, DF, Brasil. E-mail: nubia. correia@embrapa.br; agnaldo.carvalho@embrapa.br

* Author for correspondence 


\section{Introduction}

Potato (Solanum tuberosum L.) is one of the main crops grown in Brazil and is the third most important human food crop in the world after rice and wheat. In 2016, 19 million hectares around the world had been planted with potatoes, with a production greater than 376 million tons (FAOSTAT, 2018). The overall potato yield in Brazil in the agricultural year of 2017 was 3.8 million tons, from 130 thousand hectares. The state of Minas Gerais is the main national producer, accounting for $32.7 \%$ of the total national production, followed by Paraná (20.1\%) and São Paulo (17.3\%) (IBGE, 2017).

Several biotic factors are responsible for quantity depreciation and tuber quality in potato cultivation. One of these is weed interference, which is controlled mainly by herbicide application. Nevertheless, despite its numerous advantages, chemical control requires precautions. The chosen chemical treatment (i.e., the combination of herbicide, product associations, dose, and time of application) should also take into account the selectivity of the cultivar of interest. Selectivity is the measure of the differential response of various plant species to a given herbicide, and is fundamental to the success of chemical weed control. The higher the difference in tolerance between the cultivar and the weed, the safer the application is (OLIVEIRA JÚNIOR; INOUE, 2011).

According to potato growers, metribuzin is the most commonly used herbicide for potato cultivation in Brazil. Still, most reports in the literature on its selectivity for potato plants (ALEBRAHIM et al., 2012; BOYDSTON et al., 2012; DITTMAR et al., 2015; FELIPE et al., 2006; GRICHAR et al., 2003; HUTCHINSON et al., 2005a,b, 2006; HUTCHINSON, 2007; WILSON et al., 2002; ZAGONELetal., 1999a,b) study only pre-emergence applications. Metribuzin inhibits electron transport in Photosystem II at the photochemical stage of photosynthesis, is a triazinone, and is registered for potato cultivation at doses of 360 and $720 \mathrm{~g} \mathrm{ha}^{-1}$ in pre-emergence or up to a $5.0 \mathrm{~cm}$ height for early applications (RODRIGUES; ALMEIDA, 2011).

In the field, potato growers use lower doses of metribuzin (up to $480 \mathrm{~g} \mathrm{ha}^{-1}$ ) because of concerns regarding phytotoxicity and because of the practice of the hilling. During hilling, which is carried out 20 to 30 days after emergence, part of the herbicide available in the soil between cultivar lines is lost by degradation. This compromises weed control maintenance in the area. There are herbicides registered and selective for the crop for postemergence applications, namely in the case of new periods of emergence for grass species from the Poaceae family. However, there is no chemical control option for broadleaf species (eudicots). Therefore, some producers apply lower doses of metribuzin after hilling to complement the residual effect. However, no studies have demonstrated the post-emergence selectivity of metribuzin in the case of pre-emergence application.

The hypothesis of this study was that the potato, regardless of the cultivar, is more sensitive to metribuzin for post-emergence application. As such, the Agata and Atlantic potato cultivars were studied for the selectivity of pre- and post-emergence applications.

\section{Materials and Methods}

Two experiments were carried out in a commercial potato production area in Cristalina, Goiás State, one with the Agata cultivar (from May 24 to September 9, 2016) and another with the Atlantic cultivar (from May 25 to September 28, 2016).

The potato cultivars were selected according to the representativeness of the planted area in Brazil, acceptability of the in natura market and use for industry (processing).

The Agata and Atlantic experiments took place at altitudes of 941 and 974 meters and at latitudes of $16^{\circ} 12^{\prime} 36.0^{\prime \prime} \mathrm{S}$ and $16^{\circ} 11^{\prime} 11.0^{\prime \prime} \mathrm{S}$ and longitudes of $47^{\circ} 27^{\prime} 38.4^{\prime \prime} \mathrm{W}$ and $47^{\circ} 28^{\prime} 23.4^{\prime \prime} \mathrm{W}$, respectively. 
The climate of the region has an Aw Köppen classification - specifically, tropical humid, but with a dry winter (CARDOSO et al., 2014). The soil of the experimental areas is representative of the region and is classified as Dark Red Latosol, with a clayey texture for the Agata experiment and a very clayey texture for the Atlantic. The Agata and Atlantic soils had organic matter contents of 2.5 and $1.8 \mathrm{dag} \mathrm{kg}^{-1}$, respectively.

A randomized block experimental design, with a subdivided plot $(5 \times 3)$ and four replications, was used in both experiments. Plot experiments consisted of five doses of metribuzin $(0,120,240$, 360 , and $480 \mathrm{~g}$ a.i. ha $\mathrm{h}^{-1}$ ) studied for pre-emergence, as well as three doses $\left(0,120\right.$, and $192 \mathrm{~g}$ a.i. ha $\left.{ }^{-1}\right)$ studied for post-emergence. The Agata and Atlantic plants were 12.2 and $28.4 \mathrm{~cm}$ in height, respectively, at the time of the second application.

The plots were $2.4 \mathrm{~m}$ wide (three potato lines) and $15.0 \mathrm{~m}$ long. The subplots were demarcated within them ( $2.4 \mathrm{~m}$ wide and $5.0 \mathrm{~m}$ long), with the center line and $3.0 \mathrm{~m}$ of length as useful area, totaling $2.4 \mathrm{~m}^{2}$.

The soil was plowed once and harrowed twice, after which it was treated with a rotating hoe. Planting was mechanized (Grimme planter), and occurred on May 24, 2016 for the Agata cultivar and May 25, 2016 for the Atlantic cultivar. Spacing between rows was $0.8 \mathrm{~m}$, with 3.5 seeds-potato per meter and a depth of $5.0 \mathrm{~cm}$. Base fertilization consisted of applying $3200 \mathrm{~kg} \mathrm{ha}^{-1}$ of the 03-35-06 formulation. Cover fertilization $\left(70 \mathrm{~kg} \mathrm{ha}^{-1}\right.$ potassium for both cultivars and $70 \mathrm{~kg} \mathrm{ha}^{-1}$ nitrogen for Agata) was performed along with hilling 28 days after planting (DAP) of Agata and 20 DAP of Atlantic. For the Atlantic cultivar, the nitrogen cover was introduced in installments, at 30, 45, and 60 DAP, with $25 \mathrm{~kg}$ $\mathrm{ha}^{-1}$ being distributed through irrigation water each season.

Given that planting occurred in the dry season, the areas were irrigated by a central pivot, with the plants receiving the indicated volume of water for the cultivar, measured for each cycle. All plots were kept without weeds until harvest, with manual elimination of all weeds that survived chemical treatment in the control and all weeds that grew in the treatment without herbicide.

The herbicide was applied using a coastal sprayer, maintained at a constant pressure of $3.4 \mathrm{kgf}$ $\mathrm{cm}^{-2}$ with $\mathrm{CO}_{2}$. The sprayer was equipped with a bar with four spray nozzles TTI 110015 , spaced $0.5 \mathrm{~m}$ and with a spray volume equivalent to $200 \mathrm{~L} \mathrm{ha}^{-1}$.

Possible visible damage to the potato plants was evaluated at 15,30 , and 45 days after pre-emergence herbicide application, using a grading scale from 0 to $100 \%$, where zero represents no visual injuries and 100 indicates plant death.

On the day of harvest (September 9, 2016 for Agata and September 28, 2016 for Atlantic), the potato plants of the subplot useful area $\left(2.4 \mathrm{~m}^{2}\right)$ were counted and the plant population per hectare was estimated (one thousand plants $\mathrm{ha}^{-1}$ ). Then, all the tubers from the subplots were removed from the soil and were classified as either commercial (further subdivided into groups of diameter greater than $45 \mathrm{~mm}$, diameter of 20 to $44 \mathrm{~mm}$, and total) or discard. They were then counted and weighed, thereby yielding the quantity and fresh mass per subplot. Yield and quantity were measured in $\mathrm{tha}^{-1}$ and thousand units $\mathrm{ha}^{-1}$, respectively, for both the commercial and discard groups. Only perfect tubers (no deformation or cracks; free of insects, fungus, and bacteria) with a diameter greater than $20 \mathrm{~mm}$ were selected as commercially productive and counted. The others were classified as discarded for the Agata and as discarded or cracked for Atlantic.

The Atlantic cultivar was evaluated separately from the other discarded tubers due to its higher number of cracked tubers. The cracked tubers were weighed and counted to obtain the yield and quantity of cracked Atlantic tubers per hectare.

The analysis of variance $F$-test was used to evaluate the data obtained in each experiment. The effects of the treatments, or of their interactions, 
where significant, were compared by polynomial fit (for pre-emergence doses) or by the Tukey test at a $5 \%$ probability level (for post-emergence doses). In this case, the means test was chosen because of the reduced number of levels (only three) of this factor, and as the data distribution did not fit the linear regression model.

\section{Results and Discussion}

Metribuzin did not cause visual damage to the potato plants, regardless of the cultivar, dose, or season of application. In other studies, the herbicide applied in pre- or post-emergence caused chlorosis and necrosis to the older leaves of plants (DITTMAR et al., 2015), with phytotoxicity scores ranging from $3 \%$ to $24 \%$ (ALEBRAHIM et al., 2012). However, in some cases, the results depended on the cultivar tested (FELIPE et al., 2006), indicating a variable response among potato genotypes to the herbicide (FRIESEN; WALL, 1984).

There was no significant effect of the isolated treatments or of their interaction on any characteristic evaluated in the Agata plants (Tables 1 and 2). Specifically, the application of metribuzin (up to $480 \mathrm{~g} \mathrm{ha}^{-1}$ ) in pre-emergence combined with its post-emergence application (120 or $192 \mathrm{~g} \mathrm{ha}^{-1}$ ) did not affect plant growth or development. This confirmed the selectivity of the herbicide for this cultivar, even for post-emergence applications specifically, for plants with a height of $12.2 \mathrm{~cm}$. The tolerance to metribuzin in potato plants is associated with herbicide metabolization and reduced leaf translocation (GAWRONSKI et al., 1985).

Table 1. Analysis of variance $F$-test results for yield and quantity of commercial tubers (diameter $>45 \mathrm{~mm}$, $20>$ diameter $<44 \mathrm{~mm}$, and total) for potato var. Agata, as a function of the time of application and doses of the herbicide metribuzin.

\begin{tabular}{|c|c|c|c|c|c|c|}
\hline \multirow{3}{*}{ Sources of fluctuation } & \multicolumn{6}{|c|}{ Commercial tubers } \\
\hline & \multicolumn{3}{|c|}{ Yield } & \multicolumn{3}{|c|}{ Quantity } \\
\hline & $\phi>45 \mathrm{~mm}$ & $20>\phi<44 \mathrm{~mm}$ & Total & $\phi>45 \mathrm{~mm}$ & $20>\phi<44 \mathrm{~mm}$ & Total \\
\hline Block & $1.82 *$ & $5.96^{*}$ & $12.29 * *$ & $22.87 * *$ & $5.43^{*}$ & $23.90 * *$ \\
\hline PRE & $0.23^{\mathrm{ns}}$ & $0.11^{\mathrm{ns}}$ & $0.24^{\mathrm{ns}}$ & $0.57^{\mathrm{ns}}$ & $0.10^{\mathrm{ns}}$ & $0.43^{\mathrm{ns}}$ \\
\hline POST & $0.57^{\mathrm{ns}}$ & $2.70^{\mathrm{ns}}$ & $0.12^{\text {ns }}$ & $0.26^{\mathrm{ns}}$ & $3.18^{\mathrm{ns}}$ & $1.25^{\mathrm{ns}}$ \\
\hline PRE x POST & $1.04^{\mathrm{ns}}$ & $0.66^{\mathrm{ns}}$ & $1.10^{\text {ns }}$ & $0.42^{\mathrm{ns}}$ & $0.65^{\text {ns }}$ & $0.45^{\text {ns }}$ \\
\hline VC $1(\%)$ & 18.20 & 47.15 & 17.63 & 18.44 & 48.51 & 18.88 \\
\hline VC $2(\%)$ & 19.32 & 41.03 & 18.00 & 22.48 & 35.70 & 21.36 \\
\hline \multirow{2}{*}{ Overall mean } & \multicolumn{3}{|c|}{$\left(\mathrm{t} \mathrm{ha}^{-1}\right)$} & \multicolumn{3}{|c|}{$\left(1000\right.$ units ha $\left.^{-1}\right)$} \\
\hline & 46.58 & 6.38 & 52.97 & 290.62 & 117.36 & 407.99 \\
\hline
\end{tabular}

${ }^{n s}$ Not significant by the analysis of variance $F$-test of the Analysis of Variance. **, * Significant at $1 \%$ and $5 \%$ levels of probability, respectively, by the analysis of variance $F$-test.

In another study, the combination of pre- (556 and $842 \mathrm{~g} \mathrm{ha}^{-1}$ ) and post-emergence (556 and 278 $\mathrm{g} \mathrm{ha}^{-1}$ ) treatments with metribuzin did not interfere in the total tuber yield of the Superior, Yukon Gold, Castile, and Atlantic commercial cultivars, despite the herbicide having caused visible injury (DITTMAR et al., 2015). Similar results were obtained for the Bintje, Monalisa, Achat, and Atlantic cultivars, with 480 and $720 \mathrm{~g} \mathrm{ha}^{-1}$ of metribuzin in pre-emergence (FELIPE et al., 2006), and for Russet Burbank, treated with 280 and 420 $\mathrm{g} \mathrm{ha}^{-1}$ of the herbicide at early plant emergence (HUTCHINSON et al., 2006). 
Table 2. Analysis of variance $F$-test results for plant population, yield, and quantity of discarded tubers for potato var. Agata, as a function of the time of application and doses of the herbicide metribuzin.

\begin{tabular}{lccc}
\hline \multirow{2}{*}{ Sources of fluctuation } & Plant population & \multicolumn{2}{c}{ Discarded tubers } \\
\cline { 3 - 4 } & & $0.71^{\mathrm{ns}}$ & Quantity \\
\hline Block & $0.90^{\mathrm{ns}}$ & $0.99^{\mathrm{ns}}$ & $5.28^{*}$ \\
PRE & $0.30^{\mathrm{ns}}$ & $0.98^{\mathrm{ns}}$ & $1.60^{\mathrm{ns}}$ \\
POST & $0.51^{\mathrm{ns}}$ & $1.03^{\mathrm{ns}}$ & $1.25^{\mathrm{ns}}$ \\
PRE x POST & $0.60^{\mathrm{ns}}$ & 115.48 & $1.06^{\mathrm{ns}}$ \\
VC 1 (\%) & 8.12 & 111.20 & 59.21 \\
VC 2 (\%) & 12.66 & $\left(\mathrm{t} \mathrm{ha}^{-1}\right)$ & 49.79 \\
\hline & $-\left(1000\right.$ units ha $\left.^{-1}\right)-$ & 2.19 & $-\left(1000\right.$ units ha $\left.^{-1}\right)-$ \\
\hline
\end{tabular}

${ }^{n s}$ Not significant by the analysis of variance $F$-test of the Analysis of Variance. **, * Significant at $1 \%$ and $5 \%$ levels of probability, respectively, by the analysis of variance $F$-test.

The application of herbicides during the postemergence of potatoes is important for the control of newly emergent weeds, which can grow after hilling, depending on the planting season and on the level of site infestation. Consequently, there will be no competition between the weed and the cultivar during the critical period, and mechanized harvesting will be completed without loss or reduction in yield. Most adult weeds remaining in the area are not effectively controlled, even with the chemical desiccation of the potato plants.
The response of the Atlantic cultivar to metribuzin, on the other hand, was not similar to that recorded for Agata. The herbicide, when used in post-emergence, affected the yield and quantity of tubers with diameters between 20 and $44 \mathrm{~mm}$, as well as the total number of commercial and cracked tubers (Tables 3 and 4). However, this negative effect was only observed for the highest dose (192 g a.i. ha ${ }^{-1}$ ) (Table 5). Neither the isolated factors nor their interactions were significant for the other variables evaluated.

Table 3. Analysis of variance $F$-test results for yield and quantity of commercial tubers (diameter $>45 \mathrm{~mm}$, $20>$ diameter $<44 \mathrm{~mm}$ and total) for potato var. Atlantic, as a function of the time of application and doses of the herbicide metribuzin.

\begin{tabular}{|c|c|c|c|c|c|c|}
\hline \multirow{3}{*}{ Sources of fluctuation } & \multicolumn{6}{|c|}{ Commercial tubers } \\
\hline & \multicolumn{3}{|c|}{ Yield } & \multicolumn{3}{|c|}{ Quantity } \\
\hline & $\phi>45 \mathrm{~mm}$ & $20>\phi<44 \mathrm{~mm}$ & Total & $\phi>45 \mathrm{~mm}$ & $20>\phi<44 \mathrm{~mm}$ & Total \\
\hline Block & $0.08^{\mathrm{ns}}$ & $2.09^{\mathrm{ns}}$ & $0.77^{\mathrm{ns}}$ & $0.16^{\mathrm{ns}}$ & $1.26^{\mathrm{ns}}$ & $1.95^{\mathrm{ns}}$ \\
\hline PRE & $0.66^{\mathrm{ns}}$ & $0.11^{\mathrm{ns}}$ & $0.75^{\mathrm{ns}}$ & $0.47^{\mathrm{ns}}$ & $0.17^{\mathrm{ns}}$ & $0.44^{\mathrm{ns}}$ \\
\hline POST & $0.23^{\mathrm{ns}}$ & $12.20^{* *}$ & $2.19^{\mathrm{ns}}$ & $0.31^{\mathrm{ns}}$ & $7.66^{* *}$ & $5.33 *$ \\
\hline PRE $x$ POST & $1.62^{\mathrm{ns}}$ & $2.18^{\mathrm{ns}}$ & $1.04^{\mathrm{ns}}$ & $1.29^{\mathrm{ns}}$ & $1.23^{\mathrm{ns}}$ & $0.77^{\mathrm{ns}}$ \\
\hline VC $1(\%)$ & 26.42 & 38.11 & 18.96 & 23.50 & 51.39 & 18.92 \\
\hline VC $2(\%)$ & 18.10 & 26.54 & 15.47 & 18.44 & 36.31 & 17.83 \\
\hline \multirow{2}{*}{ Overall mean } & \multicolumn{3}{|c|}{$\left(\mathrm{t} \mathrm{ha}^{-1}\right)$} & \multicolumn{3}{|c|}{$\left(1000\right.$ units ha $\left.^{-1}\right)$} \\
\hline & 32.33 & 8.40 & 40.63 & 200.76 & 111.32 & 312.08 \\
\hline
\end{tabular}

${ }^{n s}$ Not significant by the analysis of variance $F$-test of the Analysis of Variance. **, * Significant at $1 \%$ and $5 \%$ levels of probability, respectively, by the analysis of variance $F$-test. 
One of the factors influencing cultivar selectivity of herbicides is the genotype, which is explained by changes related to absorption, translocation, metabolization, or even compartmentalization of the product. These characteristics are obtained as a function of the genetic load of the potato (NEY et al., 2016). As the cultivars of this study were not in the same experimental area, edaphoclimatic conditions should also be considered, as they directly interfere with herbicide dynamics in the soil and plant. That being said, the climatic conditions were overall very similar given the proximity of the experiments (about $1.0 \mathrm{~km}$ from each other). In addition, they were planted just one day apart from each other. Finally, the soil type and the organic matter content of the areas were also similar, with no significant differences.

Table 4. Analysis of variance $F$-test results for plant population, yield, and quantity of discarded and cracked tubers for potato var. Atlantic, as a function of the time of application and doses of the herbicide metribuzin.

\begin{tabular}{lccccc}
\hline \multirow{2}{*}{$\begin{array}{l}\text { Sources of } \\
\text { fluctuation }\end{array}$} & \multirow{2}{*}{ Plant Population } & \multicolumn{2}{c}{ Discarded tuber } & \multicolumn{2}{c}{ Cracked tuber } \\
\cline { 3 - 5 } & & Yield & Quantity & Yield & Quantity \\
\hline Block & $7.58^{* *}$ & $4.97^{*}$ & $6.91^{* *}$ & $0.12^{\text {ns }}$ & $0.26^{\text {ns }}$ \\
PRE & $0.64^{\text {ns }}$ & $1.95^{\text {ns }}$ & $1.74^{\text {ns }}$ & $1.83^{\text {ns }}$ & $2.36^{\text {ns }}$ \\
POST & $2.64^{\text {ns }}$ & $1.28^{\text {ns }}$ & $0.97^{\text {ns }}$ & $2.90^{\text {ns }}$ & $3.80^{*}$ \\
PRE x POST & $1.09^{\text {ns }}$ & $1.18^{\text {ns }}$ & $0.95^{\text {ns }}$ & $1.76^{\text {ns }}$ & $1.78^{\text {ns }}$ \\
VC 1 (\%) & 10.22 & 51.46 & 41.36 & 56.44 & 58.09 \\
VC 2 (\%) & 12.56 & 57.30 & 44.34 & 55.50 & 52.74 \\
\hline \multirow{2}{*}{ Overall mean } & $\left(1000\right.$ units ha $\left.^{-1}\right)$ & $\left(\mathrm{t} \mathrm{ha}^{-1}\right)-$ & $\left(1000\right.$ units ha $\left.^{-1}\right)$ & $-\left(\mathrm{tha}^{-1}\right)-$ & $\left(1000\right.$ units ha $\left.^{-1}\right)$ \\
\cline { 2 - 6 } & 39.79 & 0.82 & 33.89 & 77.8 & 56.67 \\
\hline
\end{tabular}

ns Not significant by the analysis of variance $F$-test of the Analysis of Variance. **, * Significant at $1 \%$ and $5 \%$ levels of probability, respectively, by the analysis of variance $F$-test.

Table 5. Yield and quantity of commercial tubers with diameters ranging from 20 to $44 \mathrm{~mm}$ and total quantity of commercial tubers (diameter $>45 \mathrm{~mm}+20>$ diameter $<44 \mathrm{~mm}$ ) and cracked tubers for potato var. Atlantic, as a function of the application of the herbicide metribuzin in pre-emergence.

\begin{tabular}{ccccc}
\hline \multirow{2}{*}{$\begin{array}{c}\text { Metribuzin } \\
\left(\mathrm{g} \mathrm{ha}^{-1}\right)\end{array}$} & \multicolumn{3}{c}{ Commercial tubers } & \multirow{2}{*}{ Cracked tubers } \\
\cline { 2 - 4 } & Yield $\left(\mathrm{t} \mathrm{ha}^{-1}\right)$ & Quantity $\left(1000\right.$ units ha $\left.^{-1}\right)$ & Total & Quantity $\left(1000\right.$ units ha $\left.^{-1}\right)$ \\
\hline 0 & $8.86 \mathrm{a}^{(1)}$ & $112.29 \mathrm{ab}$ & $309.79 \mathrm{ab}$ & $53.33 \mathrm{ab}$ \\
120 & $9.92 \mathrm{a}$ & $135.83 \mathrm{a}$ & $341.87 \mathrm{a}$ & $45.62 \mathrm{a}$ \\
192 & $6.50 \mathrm{~b}$ & $85.83 \mathrm{~b}$ & $284.58 \mathrm{~b}$ & $71.04 \mathrm{~b}$ \\
DMS & 1.74 & 31.52 & 43.39 & 23.31 \\
\hline
\end{tabular}

(1) Means followed by the same letter in the column do not differ significantly by the Tukey test at a 5\% probability level.

In studies on metribuzin selectivity for the Atlantic cultivar, the yield data presented refer to the total yield of commercial tubers; in none of the studies did the herbicide negatively interfere with yield (FELIPE et al., 2006; DITTMAR et al., 2015). In this study, the total yield of commercial tubers 
was also not affected by the herbicide. Overall, $82 \%, 76 \%$, and $78 \%$ of the commercial tubers had a diameter greater than $45 \mathrm{~mm}$ for 192, 120, and $0 \mathrm{~g} \mathrm{ha}^{-1}$ of metribuzin, respectively. Consequently, the percentage of tubers with a diameter of 20-44 mm was $18 \%, 24 \%$, and $22 \%$ for 192,120 , and 0 $\mathrm{g} \mathrm{ha} \mathrm{a}^{-1}$ of metribuzin, respectively. Although the highest dose of metribuzin affected the yield of tubers with a diameter of 20 to $44 \mathrm{~mm}$, the total yield of commercial tubers was not affected, as the percentage of larger tubers in the sample increased. This does not compromise the profitability of the grower; indeed, overall income should increase, given the increased yield of potatoes of greater value.

The difference in the percentage of tubers with a larger or smaller diameter can be justified by physiological changes in the plants, especially in the source-drain relationship caused by the application of metribuzin in the post-emergence period. In this case, the herbicide inhibited the formation of smaller tubers. In turn, the plant stimulated the growth of tubers in formation and already formed. A change in the glucose/fructose ratio in the process of metribuzin metabolization by Atlantic plants is assumed, thereby being responsible for the inhibition of tuber formation; the glucose/fructose ratio is associated with the onset of tuber formation and is significantly increased at the extremities of the stolons (DAVIES, 1984). Therefore, the difference in response between Atlantic and Agata cultivars can be explained by the differential ability of metabolizing metribuzin, coupled with the larger planting-harvest cycle of Atlantic - in this case, 126 days versus 108 days. The Atlantic tubers, for being destined to the processing in the form of chips, should accumulate more dry matter (MÜLLER et al., 2009), which is obtained, among other factors, by the maturity of the tubers, due to the permanence of the plants in the field.

The hypothesis that both potato cultivars would be more sensitive to metribuzin when applied in post-emergence was not confirmed in this study.
This study demonstrated that metribuzin was selective for the Agata and Atlantic cultivars at doses of up to $480 \mathrm{~g} \mathrm{ha}^{-1}$ in pre-emergence combined with 120 or $192 \mathrm{~g} \mathrm{ha}^{-1}$ in post-emergence, sprayed seven days after hilling. These results are important for potato growers, who can apply this herbicide after hilling, thereby avoiding cultivar damage due to competition with weeds or weed interference during mechanized harvest.

\section{Conclusion}

Metribuzin applied in pre $(120,240,360,480 \mathrm{~g}$ $\mathrm{ha}^{-1}$ ) and post-emergence (120 and $192 \mathrm{~g} \mathrm{ha}^{-1}$ ), and the combination of the doses in the two application periods, was selective for the Agata and Atlantic potato cultivars.

\section{Acknowledgements}

Thanks to Agrícola Wehrmann, specifically agricultural engineer Rodrigo Ribeiro, the production manager, who provided the areas for the field experiments.

\section{References}

ALEBRAHIM, M. T.; MAJD, R.; RASHED MOHASSEL, M. H. R.; WILCOCKSON, S.; BAGHESTANI, M. A.; GHORBANI, R.; KUDSK, P. Evaluating the efficacy of pre- and post-emergence herbicides for controlling Amaranthus retroflexus L. and Chenopodium album L. in potato. Crop Protection, Oxford, v. 42, n. 1, p. 345-350, 2012.

BOYDSTON, R. A.; FELIX, J.; AL-KHATIB, K. Preemergence herbicides for potential use in potato production. Weed Technology, Lawrence, v. 4, n. 26, p. 731-739, 2012.

CARDOSO, M. R.; MARCUZZO, F. F.; BARROS, J. R. Classificação climática de Köppen-Geiger para o estado de Goiás e Distrito Federal. Acta Geográfica, Boa Vista, v. 8, n. 16, p. 40-55, 2014.

DAVIES, H. V. Sugar metabolism in stolon tips during early tuberization. Zeitschrift fü Pflanzenphysiologie, Stuttgart, v. 113, n. 5, p. 377-381, 1984. 
DITTMAR, P. J.; BATTS, R. B.; JENNINGS, K. M.; BELLINDER, R. R.; MEYERS, S. L. Reduced metribuzin preharvest interval on potato yield and tuber quality. Weed Technology, Lawrence, v. 29, n. 2, p. 335$339,2015$.

FELIPE, J. M.; MARTINS, D.; COSTA, N. V. Seletividade de herbicidas aplicados em pré-emergência sobre cultivares de batata. Bragantia, Campinas, v. 65, n. 4, p. 615-621, 2006.

FOOD AND AGRICULTURE ORGANIZATION OF THE UNITED NATIONS - FAOSTAT. Agriculture Organization of the United Nations Statistics Division (2016). Available at: <http://www.fao.org/faostat/ en/\#data/QC/visualize>. Accessed at: 07 mar. 2018.

FRIESEN, G. H.; WALL, D. A. Response of potato (Solanum tuberosum) cultivars to metribuzin. Weed Science, Lawrence, v. 32, n. 4, p. 442-444, 1984.

GAWRONSKI, S. W.; HADERLIE, L. C.; CALLIHAN, R. H.; DWELLE, R. B. Metribuzin absorption, translocation, and distribution in two potato (Solanum tuberosum) cultivars. Weed Science, Lawrence, v. 33, n. 5, p. 629-634, 1985.

GRICHAR, W. J.; BESLER, B. A.; BREWER, K. D. Purple nutsedge control and potato (Solanum tuberosum) tolerance to sulfentrazone and halosulfuron. Weed Technology, Lawrence, v. 17, n. 3, p. 485-490, 2003.

HUTCHINSON, P. J. S. Comparison of flumioxazin and rimsulfuron tank mixtures for weed control in potato. Weed Technology, Lawrence, v. 21, n. 4, p. 1023-1028, 2007.

HUTCHINSON, P. J. S.; BRENT, B. R.; HANCOCK, D. Weed control and potato (Solanum Tuberosum) crop response with low rates of sulfentrazone applied postemergence with metribuzin. Weed Technology, Lawrence, v. 20, n. 4, p. 1023-1029, 2006.

HUTCHINSON, P. J. S.; HANCOCK, D. M.; BEUTLER, B. R. Efficacy of reduced sulfentrazone rates applied preemergence with metribuzin in potato (Solanum tuberosum). Weed Technology, Lawrence, v. 19, n. 4, p. 954-958, 2005b.
HUTCHINSON, P. J. S.; RANSOM, C. V.; BOYDSTON, R. A.; BEUTLER, B. R. Dimethenamid-p: efficacy and potato (Solanum tuberosum) variety tolerance. Weed Technology, Lawrence, v. 19, n. 4, p. 966-971, 2005a.

INSTITUTO BRASILEIRO DE GEOGRAFIA E ESTATÍSTICA - IBGE. Levantamento sistemático da produção agrícola: pesquisa mensal de previsão e acompanhamento das safras agrícolas no ano civil. Rio de Janeiro: IBGE, v. 30, n. 12, p. 1-82, 2017.

MÜLLER, D. R.; BISOGNIN, D. A.; ANDRIOLO, J. L.; MORIN JUNIOR, G. R.; GNOCATO, F. S. Expressão dos caracteres e seleção de clones de batata nas condições de cultivo de primavera e outono. Ciência Rural, Santa Maria, v. 39, n. 5, p. 1237-1334, 2009.

NEY, V. G.; TERRES, L. R.; SILVA, G. O. da; PEREIRA, A. da S. Expected response to early-generation selection for yield and tuber appearance traits in potatoes. Semina: Ciências Agrárias, Londrina, v. 37, n. 5, p. 2849-2858, 2016.

OLIVEIRA JÚNIOR, R. S.; INOUE, M. H. Seletividade de herbicidas para culturas e plantas daninhas. In: OLIVEIRA JÚNIOR, R. S.; CONSTANTIN, J.; INOUE, M. H. (Ed.). Biologia e manejo de plantas daninhas. Curitiba: Omnipax, 2011. p. 243-262.

RODRIGUES, B. N.; ALMEIDA, F. L. S. Guia de herbicidas. 6. ed. Londrina: Edição dos Autores, 2011. 697 p.

WILSON, D. E.; NISSEN, S. J.; THOMPSON, A. Potato (Solanum tuberosum) variety and weed response to sulfentrazone and flumioxazin. Weed Technology, Lawrence, v. 16, n. 3, p. 567-574, 2002.

ZAGONEL, J.; REGHIN, M. Y.; MORESCO, E. Controle de plantas daninhas na cultura da batata. Horticultura Brasileira, Brasília, v. 17, n. 1, p. 65-67, 1999a.

ZAGONEL, J.; REGHYN, M. Y.; VENÂNCIO, W. S. Avaliação de herbicidas de pós-emergência na cultura da batata. Horticultura Brasileira, Brasília, v. 17, n. 1, p. 67-69, 1999 b. 